\title{
The Corporation and the Constitution: Economic Due Process and Corporate Speech
}

Corporations have never been granted the vote. ${ }^{1}$ Constitutional protection for participation by corporations ${ }^{2}$ in politics is therefore afforded principally by the speech and press clauses of the First Amendment. ${ }^{3} \mathrm{Al}-$ though the precise extent of this protection has long been unclear, ${ }^{4}$ a number of recent cases have begun to resolve the question. The most significant of these, First National Bank of Boston v. Bellotti, ${ }^{5}$ held that corporations enjoy some measure of freedom of speech. ${ }^{6}$.

1. But see Salyer Land Co. v. Tulare Water Dist., 410 U.S. 719 (1973) (voting rights in water storage district may be apportioned to property owners, including corporations, in proportion to holdings). Justice Douglas, joined by Justices Brennan and Marshall, writing in dissent, protested that corporations were not citizens for the purposes of the vote. Id. at 741. His contention, which certainly holds true in less specialized settings, raises a paradox of corporate speech. A corporate person can wield more influence in politics through speech activities than it could by exercising a vote. If the purpose of the vote is to allow each citizen to influence the political process, the defender of corporate speech may find it difficult to explain why there should not be corporate suffrage.

2. This Note uses the terms "corporate person" and "corporation" to refer to all forms of business association possessing a fictitious legal personality.

3. U.S. CONST. amend. I ("Congress shall make no law . . . abridging the freedom of speech, or of the press ....")

4. For example, the Supreme Court has never determined the constitutionality of the Federal Corrupt Practices Act, 2 U.S.C. \$ 441b (1976), which prohibits corporate and union contributions and expenditures in connection with federal elections, although the Act has been repeatedly challenged over the past fifty years on First Amendment grounds. See note 24 infra. The reluctance of the Supreme Court to address these issues may reflect the sheer difficulty of defining an appropriate political role for corporations within a democracy. Even democratic theorists identified with pluralism-a viewpoint one would imagine most likely to accommodate corporations-have found it difficult to define such a role. See R. DAHL, AFTER THE REVOLUTION? 115-40 (1970) (power presently wielded by corporate owners and managers cannot be justified on the basis of democratic principles); C. LIND. BLOM, POLITICS AND MARKETS 356 (1977) ("More than class, the major specific institutional barrier to fuller democracy may therefore be the autonomy of the private corporation.")

5. 435 U.S. 765 (1978) (invalidating Massachusetts statute restricting use of corporate funds to influence outcome of state referendum).

6. Id. at 795. The Court drew short of holding that the speech rights of corporations were necessarily identical to those of natural persons. Id. at $777 \mathrm{n} .13$.

A significant literature already exists commenting on the Bellotti decision. Some commentators have defended Bellottj as an appropriate doctrinal development. See, e.g., The Supreme Court, 1977 Term, 92 HARV. L. REV. 57, 163-74 (1979); Note, First National Bank of Boston v. Bellotti: Money Talks: Constitutional Protection of Corporate Political Speech, 8 CAP. U.L. REV. 575 (1979). Others have expressed concern about the effects of Bellotti on the role of the individual in politics, see, e.g., Hart \& Shore, Corporate Spending on State and Local Referendums. First National Bank of Boston v. Bellotti, 29 CASE W. RES. L. REV. 808 (1979), and about the effects of Bellotti on the rights of minority shareholders, see, e.g., Political Contributions-First National Bank of Boston v. Bellotti-Another Hurdle for Sharcholder Protection, 4 J. CORPORATION L. 460 (1979). Other commentators have criticized the theoretical bases for the Court's decision. See, e.g., Chevigny, Philosophy of Language and Free Expression, 55 N.Y.U. L. REV. 157, 189-90 (1980) (Bellotti denies First Amendment interest in preventing one-sided political dialogue); O'Kelley, The Constitutional Rights of Corporations Revisited: Social and Political Expression after First National Bank v. Bellotti, 67 GEO. L.J. 1347 (1979) 
The issue of corporate constitutional rights is not new, the first such rights having been recognized slightly less than a century ago.' Since the late 1930's, however, with the judicial repudiation of economic due process and the ratification of the New Deal, the fact that corporations are entitled to constitutional rights has tended to be viewed as a matter of limited consequence. ${ }^{8}$ This is principally because post-New Deal constitutional courts have given little emphasis to the economic rights traditionally of the greatest interest to corporations. This Note argues that the Court's grant of First Amendment rights to corporations, which considerably enhanced corporate power relative to elected legislatures, requires that the issue of corporate constitutional rights be considered once again.

Much of the conceptual difficulty posed by this area of law stems from vagueness in our understanding of the ideas of "rights" and "powers" in the context of American liberal democracy. For this reason, after summarizing the law on the constitutional corporate person, this Note sets forth an outline of liberal democratic theory pertinent to the issue of corporate constitutional rights. The Note then reviews the constitutional consequences of the rapid growth in importance of the private corporation during the nineteenth and twentieth centuries. The Note emphasizes certain salient changes in constitutional law concerning property rights, changes that distinguish the era of industrialization culminating in economic due process from the earlier Jacksonian era and, in turn, distinguish the present post-New Deal era from the era of economic due process. The Note then argues that by reaffirming and extending the entitlement of corporations to constitutional rights, the Gourt in Bellotti rendered a decision strongly reminiscent of the economic due process era, one marking an important departure from post-New Deal constitutional jurisprudence to date. Both corporate speech and economic due process represent attempts by the Court to resolve in constitutional law a conflict between the premises of liberal democratic theory and the exercise of power by private business corporations. Both attempts resolve the conflict by denying that corporations do, in fact, exercise power of any consequence for constitutional analysis. The Note argues further that granting First Amendment rights to corporations does not serve any free expression interests. The Note concludes that the Bellotti decision was unwise and should be overturned.

(corporate rights should be recognized when it would be appropriate to extend them to unincorporated association; Bellotti mistakenly conceives corporations as entities having rights distinct from those of members).

7. See Santa Clara County v. Southern Pac. R.R., 118 U.S. 394 (1886); p. 1835 infra (discussing Santa Clara).

8. See p. 1860 \& note 143 infra. 


\section{Corporate Personality and the Constitution}

For constitutional purposes, corporate personality gained no more than bare legal recognition in federal courts until $1886 .{ }^{\circ}$ In that year, during a colloquy with counsel in Santa Clara County v. Southern Pacific Railroad, ${ }^{10}$ Chief Justice Waite stated the Court's opinion that the term "person" in the equal protection clause of the Fourteenth Amendment ${ }^{11}$ encompassed corporations. ${ }^{12}$ Subsequent cases extended additional constitutional rights to corporations ${ }^{13}$ while withholding others. ${ }^{14}$

The repudiation of economic due process in the late 1930s and with it most of the Court's role in supervising economic legislation might have included a repudiation of the doctrine that corporate persons are entitled to constitutional rights-as Justice Black recommended in 1938 in the context of the Fourteenth Amendment. ${ }^{15}$ Instead, the doctrine survived ${ }^{16}$

9. The right of corporations to sue in federal court was established in 1809. See Bank of the United States v. Deveaux, 9 U.S. (5 Cranch) 61, 88, 91 (1809) (shareholders may appear in federal court under corporate name). Before enactment of the Civil War amendments, efforts to make corporations beneficiaries of substantive constitutional protections focused on the privileges and immunities clause of Article IV, section 2, and were unsuccessful. See Bank of Augusta v. Earle, 38 U.S. (13 Pet.) 519, 586-87 (1839) (term "citizen" in privileges and immunities clause does not include corporations); cf. Graham, An Innocent Abroad: The Constitutional Corporate Person, 2 U.C.L.A. L. REV. 155, 167 (1955) (attention by corporate lawyers to possibilities under Fourteenth Amendment emerged after complete collapse of efforts under Article IV privileges and immunities clause).

10. 118 U.S. 394 (1886).

11. U.S. CONST, amend. XIV, $\$ 1$ ("[No State shall] deny to any person within its jurisdiction the equal protection of the laws.")

12. 118 U.S. at 396. United States Reports reads:

Before argument MR. CHIEF JUSTICE WAITE said: The Court does not wish to hear argument on the question whether the provision in the Fourteenth Amendment to the Constitution, which forbids a state to deny to any person within its jurisdiction the equal protection of the laws, applies to these corporations. We are all of opinion that it does.

Subsequent cases affirmed this reading of the equal protection clause. See Louis K. Liggett Co. v. Lee, 288 U.S. 517, 536 (1933); Pembina Mining Co. v. Pennsylvania, 125 U.S. 181, 189 (1888).

13. The Court has held that corporations are entitled to due process of law, Noble v. Union River Logging R.R., 147 U.S. 165, 176 (1893) (Fifth Amendment); Minneapolis \& St. L. Ry. v. Beckwith, 129 U.S. 26, 28, 36 (1889) (Fourteenth Amendment), freedom from unreasonable searches and seizures under the Fourth Amendment, Hale v. Henkel, 201 U.S. 43, 76 (1906), protection against double jeopardy under the Fifth Amendment, Puerto Rico v. Shell Co., 302 U.S. 253, 264 (1937) (by implication), and freedom of the press under the First Amendment as applied to the states through the Fourteenth Amendment, Grosjean v. American Press Co., 297 U.S. 233, 244 (1936).

14. Before the decision in Santa Clara, the Court had denied corporations rights under the privileges and immunities clause of Article IV, Section 2, of the Constitution. See note 9 supra. Subsequent cases denied corporations privileges and immunities under the Fourteenth Amendment, Orient Insurance Co. v. Daggs, 172 U.S. 557, 560-61 (1889), and the privilege against self-incrimination under the Fifth Amendment, Hale v. Henkel, 201 U.S. 43, 75 (1906). The Court has also indicated that corporations do not enjoy a right of privacy equivalent to that of individuals. California Bankers Ass'n v. Schultz, 416 U.S. 21, 65 (1974).

15. Connecticut Gen. Life Ins. Co. v. Johnson, 303 U.S. 77, 85-90 (1938) (Black, J., dissenting); see Wheeling Steel Corp. v. Glander 337 U.S. 562, 576-81 (1949) (Douglas, J., dissenting).

16. The Court recognized no new constitutional protections for corporations between 1937 and 1978, although no right's that had previously been extended were withdrawn.

In a number of cases decided before Bellotti, the Court upheld First Amendment claims brought by institutional litigants, though it did so without reference to their corporate status. E.g., Time Inc. v. Firestone, 424 U.S. 448 (1976) (upholding First Amendment rights of news magazine); Southeastern 
and was recently reaffirmed in Bellotti. Citing Santa Clara, the Bellotti Court held that corporations were entitled to freedom of speech as an element of their due process rights under the Fourteenth Amendment. ${ }^{17}$ Corporations may now claim some degree of constitutional protection for expenditures of money ${ }^{18}$ for commercial ${ }^{19}$ as well as political speech.

Federal legislation has regulated corporate political speech since $1907 .{ }^{20}$ The current law, known as the Federal Corrupt Practices Act (FCPA), ${ }^{21}$ makes criminal any expenditure of corporate funds in connection with a federal election..$^{22}$ In addition, twenty-six states have legislation regulating corporate participation in state elections. ${ }^{23}$ The constitutionality under the

Promotions, Ltd. v. Conrad, 420 U.S. 546 (1975) (upholding First Amendment rights of theatrical promoter); see First Nat'l Bank of Boston v. Bellotti, 435 U.S. 765, 778 n.14 (1978) (citing other cases).

17. First Nat'l Bank of Boston v. Bellotti, 435 U.S. 765, 780 (1978). The Court did not cite the holding of Hague v. CIO, 307 U.S. 496, 514, 527 (1939), in which a majority of Justices, on differing grounds, held that corporate persons were not entitled to freedom of speech.

18. Since corporations are fictitious persons, "corporate speech," as distinguished from speech by individual managers or other employees of a corporation, is, strictly speaking, a flow of cash or other use of corporate property to disseminate speech. See First Nat'l Bank of Boston v. Bellotti, 435 U.S. 765, 786 n.23 (1978); cf. Note, Corporate Political Affairs Programs, 70 Yale L.J. 821 (1961) (discussing methods available to corporations to put resources to political advantage). Expenditure of money to support speech activities comes within the protection of the First Amendment. Buckley v. Valeo, 424 U.S. 1, 16 (1976). But see Wright, Politics and the Constitution: Is Money Speech? 85 YALE L.J. 1001 (1976) (criticizing Buckley's identification of political contributions and expenditures with pure speech rather than speech-related conduct). Judge Wright does not deny that expenditure of money is generally essential for speech by individuals and is entitled to some degree of constitutional protection, though not that afforded pure speech. Id. at 1006. This Note argues that the availability of corporate funds for speech activities serves no First Amendment interests. See p. 1856 infra.

19. See Central Hudson Gas \& Elec. Corp. v. Public Serv. Comm'n, 100 S. Ct. 2343 (1980). Although the Court has held that commercial speech, including advertising, enjoys First Amendment protection, Virginia Bd. of Pharmacy v. Virginia Citizens Council, 425 U.S. 748, 770 (1976) (overruling Valentine v. Chrestensen, 316 U.S. 52 (1942)), it has conceded that a "commonsense" distinction remains between commercial and political speech and that commercial speech is entitled to a lesser degree of protection. 425 U.S. at 771 n.24. Compare Central Hudson Gas \& Elec. Corp. v. Public Serv. Comm'n, 100 S. Ct. 2343, 2350 (1980) (commercial speech protected by First Amendment if it does not concern unlawful activity and is not misleading) with Brandenburg v. Ohio, 395 U.S. 444, 448-49 (1969) (political speech advocating criminal act, unless "incitement to imminent lawless action," entitled to First Amendment protection) and Gertz v. Robert Welch, Inc., 418 U.S. 323, 339 (1974) (under First Amendment there is "no such thing" as false political idea).

20. The Tillman Act of 1907 , ch. 420,34 Stat. 864 (1907) (current version at 2 U.S.C. \$ 441 b (1976)), prohibited any national bank or corporation from making monetary contributions in connection with any election to any political office. It also prohibited any corporation from contributing money in connection with any federal election. For a history of federal corrupt practices legislation, see United States v. United Auto Workers, 352 U.S. 567, 570-90 (1957); Lambert, Corporate Political Spending and Campaign Finance, 40 N.Y.U. L. REV. 1033, 1035-40 (1965).

21. 2 U.S.C. $\S 441 \mathrm{~b}(1976)$. The present statute applies to labor unions and national banks as well as corporations.

22. Id. $\S 441 \mathrm{~b}(\mathrm{a})$. The FCPA does, however, authorize "the establishment, administration, and solicitation of contributions to a separate segregated fund to be utilized for political purposes by the corporation . . . " Id. \$ 44lb(b)(2)(C).

23. See ALA. CODE § 17-22-3 (1975 \& Supp. 1980); ARIZ. REV. STAT. ANN. § 16-471 (1975); IND. CODE ANN. § 3-4-3-3 (Burns Supp. 1980); IOWA CODE ANN. $\S 56.29$ (West Supp. 1980); KAN. STAT. ANN. § 25-1709 (1973); KY. REV. STAT: §§ 121.025, 121.035 (Supp. 1980); LA. REV. STAT. ANN. § 18:1482-:1483 (West 1979 \& Supp. 1980); ME. REV. STAT. ANN. tit. 21, § 1395(2) (Supp. 1980); MASS. ANN. L $\Lambda$ WS ch. $55 \S 8$ (Michie/Law. Co-op 1978); MINN. STuT. ANN. § $210 A .34$ 
First Amendment of the FCPA or of similar state statutes has never been determined by the Supreme Court. ${ }^{24}$ The "corporate speech" doctrine announced in Bellotti, however, appears to foreclose the possibility of legally restricting corporate political participation in connection with referenda ${ }^{25}$ and may also cripple federal and state legislation concerning candidate elections. $^{26}$

\section{The Liberal Democratic Conception of Individual Rights}

Liberal democracy ${ }^{27}$ embraces a balance or tension. On one side is the power of a democratic majority to govern and, if so motivated, to effect social change; on the other side are limitations on governmental power

(West Supp. 1981); MISS. CODE ANN. §§ 97-13-15, -13-17 (Supp. 1980); MONT. CODE ANN. § 1335-227 (1979); N.H. REV. STAT. ANN. § 70:2(I) (1970); N.J. STAT. ANN. § 19:34-45 (West 1964); N.Y. ELEC. LAW § 14-116 (McKinney 1978); N.C. GEN. STAT. § 163-278.19 (1976 \& Supp. 1979); N.D. CENT. CODE § 16.1-08-02 (Supp. 1979); OHIO REV. CODE ANN. § 3599.03 (Page 1972); OKLA. STAT. ANN. tit. 26, $\S 15-110$ (West Supp. 1980); OR. REV. STAT. $\S 260.415$ (1979); S.D. COMP. LAWS ANN. § 12-25-2 (Supp. 1980); TENN. CODE ANN. § 2-19-132 (1979); TEX. ELEC. CODE ANN. art. 14.06 (Vernon Supp. 1980); W. VA. CODE § 3-8-8 (1979); WIS. STAT. ANN. § 11.38 (West Supp. 1980-81); WYO. STAT. $§ 22-25-102$ (1977). About ten states have statutes applying restrictions to corporate spending that might be broad enough to cover referenda. See Fox, Corporate Political Spech: The Effect of First National Bank of Boston v. Bellotti Upon Statutory Limitations on Corporate Referendum Spending, 67 KY. L.J. 75, 84 (1978-79).

24. Cases challenging federal corrupt practices legislation have reached the Court, but so far it has been able to avoid the constitutional issue. See Cort v. Ash, 422 U.S. 66, 85 (1975) (prohibition against corporate political expenditures held to create no shareholder right of action); Pipefitters Local 562 v. United States, 407 U.S. 385, 440 (1972) (remanding case to district court because of erroneous construction of corrupt practices act); United States v. United Auto Workers, 352 U.S. 567, 592 (1957) (same); United States v. CIO, 335 U.S. 106, 124 (1948) (statute interpreted not to prohibit speech activities at issue).

25. See Fox, supra note 23 , at 85,101 . There is at present no federal referendum process.

26. The relevance of Bellotti to the FCPA and hence to state statutes governing elections was left somewhat unclear by the Court's suggestion that the Bellotti holding might be limited to referenda as distinguished from candidate elections, which involve the additional factor of possible corruption. First Nat'l Bank of Boston v. Bellotti, 435 U.S. 765,788 n.26 (1978). But see Birnbaum, The Constitutionality of the Federal Corrupt Practices Act after First National Bank of Boston v. Bellotti, 28 AM. U.L. REV. 149, 168, 175 (1979) (because Buckley v. Valeo, 424 U.S. 1 (1974), held that government's interest in preventing corruption was not sufficient to justify restrictions on independent expenditures, Bellotti leaves the Court little room to uphold FCPA).

In addition to referenda and candidate elections, the Bellotti holding appears to reach corporate lobbying. The Court cited with approval two earlier cases, California Motor Transp. Co. v. Trucking Unlimited, 404 U.S. 508 (1972), and Eastern R.R. Presidents Conference v. Noerr Motor Freight, 365 U.S. 127 (1961), that, while not addressing the corporate person issue, had upheld First Amendment claims brought by corporations engaged in administrative and legislative lobbying. 435 U.S. at 792 n.31.

27. The phrase "liberal democracy" is sometimes used in a historical sense to connote a system of government exemplified by western representative democracies. This Note treats the term as having theoretical content as well. The most comprehensive modern theoretical exposition of the term "liberal democracy" has been undertaken by Giovanni Sartori. See G. SARTORI, DEMOcRATIC THEORY 278383 (1962). But $c$. C. PATEMAN, PARTICIPATION AND DEMOcratic ThEORY 10-11 (1970) (criticizing Sartori for accepting low level of active participation in politics as essential aspect of modern democracy). Constitutional theorists may use the term "constitutional democracy" with similar connotations. See Murphy, An Ordering of Constitutional Values, 53 S. CAL. L. REV. 703, 707 n.17 (1980). 
that are tied directly or indirectly to the scope of individual rights. ${ }^{28}$ This part first sets forth the perhaps uncontroversial proposition that the Constitution is, in fact, a liberal democratic charter embracing both sides of this balance. It then reviews certain ambiguities in liberal democratic theory that render problematic the idea of corporate constitutional rights. In brief, the pertinent difficulty is determining to what extent the defense of private rights should restrain the legislature from seeking whatever degree of social equality is necessary to allow less powerful members of society actually to enjoy the benefits of those same private rights.

\section{A. The Constitutional Aspiration}

As Madison contended, the Constitution was based on a science of politics conceived to "preserve the spirit and form of popular government" while securing "the public good and private rights from the danger of [a majority] faction."29 The Constitution thus incorporated a basic dualism, embracing radical or democratic principles on the one hand and liberal principles on the other. By relying on the "sovereignty of the people" as the original justification for the Constitution and the federal government, ${ }^{30}$ the Framers preserved the legitimacy of the republic's origin in revolution and embodied in the Constitution the essential premise of radical democratic thought-that political power derives from the people. This was not idle rhetoric: subsequent generations built upon the representative mechanisms established by the document to make American constitutional government more democratic in practice. ${ }^{31}$

Yet, as the Federalists were forthright in asserting, the Constitution was also conceived to preserve private rights, particularly property rights.

28. The essential outlines of this dualism were evident in Locke's foundational Two Treatises of Civil Government, published in 1690, on which both liberal and radical democrats subsequently drew for support. See S. WOLIN, Politics AND VISION 293, 313 (1960); Minogue, The Concept of Property and its Significance, in PROPERTY: NOMOS XXII, at 3, 17 (J. Pennock \& J. Chapman eds. 1980).

29. THE FEDERAlist No. 10 (J. Madison).

30. See G. WOOD, THE CREATION OF THE AMERICAN Republic 532-36 (1969).

31. By the time of Jackson, much that was latent in American democracy had been realized politically. See Dahl, On Removing Certain Impediments to Democracy in the United States, 92 PoL. SCI. Q. 1, 2 (1977). The history of the franchise in the United States illustrates the continuing power of the rhetoric of "popular sovereignty." Property qualifications for voting were removed during the course of the nineteenth century. See K. PORTER, A HISTORY OF THE SUFFRAGE IN THE UNITED STATES 110 (1918) (nine states retained property qualification past 1800, five states past 1830, one past 1850). Successive constitutional amendments and court decisions extended the franchise to blacks, U.S. CONST. amend. XV (1870), instituted direct popular voting for U.S. senators, id. amend. XVII (1913), extended the franchise to women, id. amend. XIX (1920), eliminated white primaries, see Smith v. Allwright, 321 U.S. 649 (1944), eliminated poll taxes, U.S. CONST. amend. XXIV (1964), imposed a constitutional requirement of equitable apportionment, see Reynolds v. Sims, 377 U.S. 533 (1964), and extended the franchise to eighteen-year-olds, U.S. CONST. amend. XXVI (1971). 
By providing for indirect voting for the Senate,,$^{32}$ by reducing the legislature to a coequal branch and increasing the power and independence of the executive and judiciary, ${ }^{33}$ by centralizing power in the national government at the expense of the states, ${ }^{34}$ and by placing substantive limitations in the text of the Constitution on federal ${ }^{35}$ and state ${ }^{36}$ legislation, the Framers created a system ${ }^{37}$ that could contain the historically confirmed tendency of democracy to overturn existing property rights. ${ }^{38}$ The premises of that system were also reflected in state law: the laws of the states originally limited the franchise, for national as well as local elections, to property owners. ${ }^{39}$

\section{B. The Ambiguity of Liberal Democracy}

If liberal democracy can be characterized as embracing a tension between individual rights and collective power acting through government, then political progress in the context of liberal democracy can also be defined. Such progress would consist of change that furthers one of the two fundamental aims of a liberal democratic system-either by enhancing self-government or by securing the enjoyment of private rights-without materially sacrificing the other. ${ }^{40}$ As a rule, legislative power is threaten-

32. See U.S. CONST. art. I, $\S 3$ (superseded by Seventeenth Amendment).

33. See THE FEDERALIST No. 70 (A. Hamilton) (importance of vigorous executive as defender of property rights); THE FEDERALIST NO. 78 (A. Hamilton) (discussing importance of judiciary in safeguarding against "injury of the private rights of particular classes of citizens, by unjust and partial laws"). The federal constitutional scheme contrasted sharply with the constitutions of several state governments during the period of the Articles of Confederation that had granted legislatures powers sufficient to allow them to dominate coordinate branches. See G. WOOD, supra note 30, at 407-08.

34. See THE FEDERALIST No. 10 (J. Madison) (because constituency of national government is larger than that of any state government, there is less chance that oppressive majority faction will form); THE FEDERALIST NO. 85 (A. Hamilton) (preservation of Union will provide additional security to liberty and property by restraining local factions and "powerful individuals in single States").

35. See U.S. CONST. art. I, $\S 9$ (prohibitions against bills of attainder, ex post facto laws, and suspension of habeas corpus).

36. See id. $\S 10$ (prohibitions against emitting bills of credit or impairing obligation of contracts); cf. ThE FEDERALIST No. 85 (A. Hamilton) (Constitution provides additional securities to liberty and property in "precautions against the repetition of those practices on the part of state governments which have undermined the foundations of property and credit"). The Federalists were concerned with practices of state legislatures in issuing credit and impeding normal collection of debts. See G. WOOD, supra note 30 , at 404-05.

37. The liberal aspect of the Constitution was strengthened by the adoption of the Bill of Rights, which specified further limitations on federal power, including certain express property right guarantees. See U.S. CONST. amend. V ("[N]or [shall any person] be deprived of life, liberty, or property, without due process of law; nor shall private property be taken for public use, without just compensation."); id. amend. XIV (extending due process guarantee to states).

38. See G. WoOD, supra note 30 , at 403-09.

39. See note 31 supra.

40. Roberto Unger has argued that normative progress in politics is achieved to the extent that a given person's need and desire for autonomy is perceived as less in conflict than before with that person's need and desire for community with others. R. UNGER, KNOWLEDGE AND POLITICS 236-38 (1975). Liberal democracy can be characterized as an attempt to minimize the conflict between individual spontaneity and community power by giving all individuals a voice in the exercise of power 
ing to private rights, and private rights place limits on legislative power. This Note argues, however, that private rights can be misconceived in a way that causes a loss on both sides of the balance.

Rights protect individual autonomy and spontaneity ${ }^{41}$ from collective power exercised through legislatures and government agencies. ${ }^{42}$ In classical liberalism and in American constitutional history through the 1930s, the preeminent individual right was property.$^{43}$ Property rights help preserve individual autonomy and spontaneity by giving an owner a physical domain in the world and a basis for entering into voluntary exchange relationships with others. ${ }^{44}$ With respect to other persons, individual spontaneity is preserved if an owner may invoke property rights to call upon the state to enforce the owner's will within the domain of things owned and to enforce any voluntary agreements redistributing ownership. With respect to the state, individual spontaneity is preserved if an owner may invoke property rights to prevent the state from disturbing the integrity of that domain and the spontaneity of exchange relationships. ${ }^{45}$

This link between private property and individual freedom, however,

while guaranteeing a basic area of individual spontaneity at least partially independent of that power. Cf. Brest, The Fundamental Rights Controversy: The Essential Contradictions of Normative Constitutional Scholarship, 90 YALE L.J. 1063, 1107-09 (1981) (relationship between self and society is at root of questions posed by judicial review); Kennedy, The Structure of Blackstone's Commentaries, 28 BUFFALO L. REV. 209, 211-21 (1979) (discussing ideas of autonomy and power).

41. The term "spontaneity" is used here to expand upon the idea of "autonomy." Rights are not confined to protecting actions undertaken autonomously from others. Free expression rights, for example, may be meaningless without an audience. Property rights may protect not only personal security but also the integrity of voluntary relations with others.

42. Purely structural or procedural devices may protect citizens from arbitrary action by officials, but offer no safeguards against a threat posed by democratically enacted legislation. See L. TRIBE, AMERICAN CONSTITUTIONAL LAW 564-65 (1978) (meaningful constitutional protection requires reliance on substantive values beyond fair implementation of state's own positive decisions). John Hart Ely has developed a theory of constitutional jurisprudence ostensibly relying on only one substantive principle, democratic participation. See J. ELY, DEMOCRACY AND DISTRUST 73-104 (1980) ("representation reinforcing" theory of judicial review). Critics have persuasively argued that Ely's theory maintains its persuasiveness only by covertly relying on substantive values beyond mere participation. See Brest, supra note 40, at 1092-95; Tribe, The Puzzling Persistence of Process-Based Constitutional Theories, 89 YALE L.J. 1063, 1072-77 (1980).

43. See pp. $1842-53$ infra.

44. The association of individual freedom with autonomous property ownership distinguished liberalism from the feudal conception of ownership rights deriving from fealty and tenure. See Grey, The Disintegration of Property, in PROPERTY: NOMOS XXII, at 69, 73-74 (J. Pennock \& J. Chapman eds. 1980); cf. Vandevelde, The New Property of the Nineteenth Century: The Development of the Modern Concept of Property, 29 BUFFnLO L. REV. 325 (1980) (changing conception of property from Blackstone to ALI Restatement).

45. The scope of property rights assertable against other persons need not be identical with that of rights assertable against the state. During the late nineteenth century, the Court attempted to identify rights in both contexts with the common law. See Tribe, supra note 42, at 1066 n.9. (substantive due process theory "identified vested rights by treating the common law as a mirror of individual expectations, by regarding that which the common law protected-liberty of contract, for example-as something that individuals rightly presupposed, and upon which individuals justifiably relied"). The adoption of the "rational relation" approach to substantive due process, see p. 1850 infra, marked the abandonment of the atfempt to achieve this identity. 
glosses over a basic conceptual difficulty. At least in the context of property, the distinction between rights and powers is not always easy to maintain. The right to exclude others from something they desire or need and to enter into enforceable bargains with them provides a basis for influencing their behavior. ${ }^{46}$ Ownership of productive property permits these relationships to be maintained over time and thereby facilitates the creation of economic organization, uniting and directing the efforts of many people. Concentrated ownership of productive property and the development of private bureaucracy may in turn endow owners or managers ${ }^{47}$ with powers that in some respects resemble the powers of government. ${ }^{48}$

Thus, property has a dual nature. It is both the basis for individual autonomy and spontaneity and the basis for private power. The flaw of traditional liberal democratic theory was its failure to confront the difficulty presented by the dual nature of property: problems of power threatening to individual spontaneity can arise within the private sphere of ownership and exchange relationships. When ownership of productive property is dispersed and equitably distributed, the economic parity of citizens may be sufficient to check private power, rendering the preservation of autonomy and spontaneity primarily a matter of prudence. When ownership of productive property is concentrated, however, a guarantee of property rights can do little to protect those owning little or no property

46. Part of the defense of liberal, as distinct from democratic, ideology has been that it offers the possibility of a society in which the exercise of power is reduced overall by limiting government and reducing the public obligations of citizens and by leaving the organization of social activities as much as possible to voluntary private relationships. See S. WoLIN, supra note 28 , at 309-14. The difficulty with this claim in the context of American history is that private relations described in law as "voluntary" have, in fact, allowed considerable scope for the exercise of power. For example, placing the line distinguishing "voluntary" from legally cognizable "power" relations in the private sphere at the point separating a threat of economic deprivation in private bargaining from a threat of immediate violent harm obviously leaves a great deal of room for the exercise of influence in a "voluntary" relationship. See Dawson, Economic Duress, 45 MICH. L. REV. 253, 266-67 (1947); cf. p. 1849 infra (economic due process courts treated use of economic power in bargaining as consistent with "voluntariness" unless coercion sufficient to overcome other party's will employed).

47. Recognizing that corporate managers, in many cases, effectively exercise powers of ownership does not substantially alter the argument. See generally A. BERLE \& G. MEANS, THE MODERN CORPORATION AND PRIVATE PROPERTY 120 (1933) (position of owner of corporate enterprise has been reduced to having set of legal and factual interests in enterprise, while managers have legal and factual powers over it). The disaggregation of property rights characteristic of modern corporations does not eliminate the problem of private power. See Grey, supra note 44, at 76-79.

48. See Cohen, Property and Sovereignty, 13 CORNELl L.Q. 8, 13 (1927) (when power of corporations to tax future social product is added to power to command services of large numbers who are not economically independent, result is "essence of what historically has constituted political sovereignty"); Frug, The City as a Legal Concept, 93 HARV. L. REV. 1059, 1128-49 (1980) (arguing against common rationales for distinguishing private from municipal corporations); cf. R. DAHL, supra note 4 , at 115-21 ("[w] it is a delusion to consider it private enterprise.") At some hypothetical level of concentration, the power associated with ownership would resemble that of the absolute state. Cf. H. ARENDT, GRISES OF THE REPUBLIC 212 (1969) ("In Russia there is, of course, not socialism, but state socialism, which is the same thing as state capitalism would be-that is, total expropriation. Total expropriation occurs when all political and legal safeguards of private ownership have disappeared.") 
either from private power or from the power of the state. Any concentration of private power poses a fundamental dilemma for liberal democratic theory: to what extent should private rights prevent society from legislating whatever degree of equality is necessary for those private rights to benefit society's less powerful members?

\section{The American Career of Economic Rights}

Corporations were first granted substantive constitutional rights in $1886^{49}$ at the outset of what is now characterized as the economic due process era of constitutional adjudication, which extended from the late nineteenth century into the 1930s. It is important to see this era in historical perspective. Far from being a doctrinal aberration, economic due process had deep roots in the traditions of American constitutional jurisprudence. From the origins of the republic through the 1930s, the basic constitutional right, and the subject of virtually all constitutional litigation, was property. This tradition has been labeled the "vested rights" tradition. ${ }^{.0^{\circ}}$ In accordance with classical liberal democratic theory, it entailed an opposition between individual property rights and the legislative or police power. ${ }^{51}$ First appearing couched in terms of the "natural" or "inherent" limits on constitutional government, ${ }^{52}$ the vested rights doctrine was variously associated with the contracts clause, ${ }^{53}$ the takings clause, ${ }^{54}$

49. See p. 1835 supra.

50. See Corwin, The Basic Doctrine of American Constitutional Law, 12 MICH. L. REV. 247 (1914).

51. See id. at 246.

52. See, e.g., Terret v. Taylor, 13 U.S. (9 Cranch) 43, 50-51 (1815) (legislative revocability of land grant is "utterly inconsistent with a great and fundamental principle of a republican government, the right of the citizens to the free enjoyment of their property legally acquired"); CaIder v. Bull, 3 U.S. (3 Dall.) 386, 388 (1798) ("[Consider] a law that takes property from A. and gives it to B: It is against all reason and justice, for people to entrust a Legislature with such powers; and, therefore, it cannot be presumed that they have done it.")

53. U.S. CONST. art. I, $\S 10$, cl. 1 ("No State shall . . pass any . . . Law impairing the Obligation of Contracts . . . ."); see, e.g., McGahey v. Virginia, 135 U.S. 662 (1890) (invalidating Virginia statutes impairing negotiability of coupon bonds); McCracken v. Hayward, 43 U.S. (2 Howard) 608 (1844) (invalidating Illinois debtor statute providing that execution sale not be permitted unless proceeds will equal two thirds of its valuation, as determined by three local householders); Sturges v. Crowninshield, 17 U.S. (4 Wheat.) 122 (1819) (invalidating New York bankruptcy statute).

During the nineteenth century, the contract clause was the constitutional provision most frequently used to invalidate state laws. B. WRIGHT, THE CONTRACTS CLAUSE OF THE CONSTITUTION 91-100 (1938). Application of the contracts clause was limited, however, by the fact that the clause did not reach prospective legislation. See Ogden v. Saunders, 25 U.S. (12 Wheat.) 213 (1827) (upholding non-retroactive state insolvency statute against contracts clause challenge). The innovation brought about by the concept of "freedom of contract" under economic due process was to give common-law substance to the term "contract" capable of defeating even prospective state enactments. See note 55 infra (discussing due process clause).

54. U.S. CONST, amend. V ("[P]rivate property [shall not] be taken for public use without just compensation."); see, e.g., Monongahela Navigation Co. v. United States, 148 U.S. 312 (1893) (federal condemnation of private lock and dam required compensation not merely for tangible property but for franchise to collect tolls). The due process clause of the Fourteenth Amendment was inter- 
and the due process clause. ${ }^{55}$ Indeed, reliance on specific constitutional provisions may have been more a matter of form than substance. ${ }^{56}$

To be sure, economic due process represented a significant doctrinal innovation, expanding the scope of protections afforded property. ${ }^{57}$ More essential than doctrinal innovation to the novelty of the economic due process era, however, were socioeconomic changes: the character of the American economy was fundamentally altered by a rapid concentration in the ownership of productive property accompanying industrialization, and by the rise of the private corporation. As the significance of private property changed, so also did the significance of the constitutional defense of private property.

\section{A. The Origins of the Modern Corporation}

At the time of Jackson, productive property-mostly in the form of land-was widely, if not equitably, distributed. ${ }^{58}$ Economic enterprises

preted to include a requirement for just compensation applicable to state takings. See Chicago, B. \& Q. R.R. v. Chicago, 166 U.S. 226, 241 (1897).

55. U.S. CONST. amend. XIV, $\S 1$ ("[No state shall] deprive any person of life, liberty, or property without due process of law . . . ."); see, e.g., Liggett Co. v. Baldridge, 278 U.S. 105 (1928) (invalidating Pennsylvania statute restricting corporate ownership of pharmacies for impairing corporation's right of property in its business); Truax v. Corrigan, 257 U.S. 312, 330 (1921) (invalidating Arizona statute legalizing certain labor tactics, such as peaceful picketing and adverse publicity for impairing owner's right property in his business). A number of decisions sought to preserve rights of property by preserving "liberty of contract." See, e.g., Coppage v. Kansas, 236 U.S. 1 (1915) (invalidating Kansas statute prohibiting non-union covenants in employment contracts); Lochner v. New York, 198 U.S. 45 (1905) (invalidating New York maximum hour law for bakers). See generally W. SWINDler, COURT AND CONSTITUTION IN THE TWENTIETH CENTURY: THE OLD LEGALITY, 18981932, at 363-97 (1969) (extensive summary of constitutional cases of economic due process era).

During the economic due process era, the equal protection clause was also invoked from time to time to protect property rights. See, e.g., Truax v. Corrigan, 257 U.S. 312, 333 (1921) (invalidating Arizona statute legalizing certain labor tactics because immunity from suit "granted to a class, however limited, having the effect to deprive another class, however limited, of a personal or property right" denies equal protection); Cotting v. Kansas City Stockyards, 183 U.S. 79 (1901) (invalidating Kansas statute providing preferential treatment to small corporate stockyards).

56. Justice Brown wrote at the turn of the century:

Recognizing the difficulty in defining, with exactness, the phrase "a due process of law," it is certain that these words imply conformity with natural and inherent principles of justice, and forbid one man's property, or right to property, shall be taken for the benefit of another, or for the benefit of the State, without compensation ....

Holden v. Hardy, 169 U.S. 366, 390-91 (1898) (upholding Utah statute regulating hours of work in mines as health regulation). Paul Brest offers a contemporary analysis:

Although a positivist view of the common law became pervasive in the nineteenth century, notions of natural rights persisted in public law. Perhaps because the Court's primary justification for exercising judicial review rested on its duty to apply the positive, written law of the Constitution, later constitutional decisions almost invariably invoke particular constitutional provisions, either explicitly or by clear implication.

P. BREST, PROCESSES OF CONSTITUTIONAL DECISIONMAKING 712 (1975) (footnote omitted).

57. See note 53 supra (comparing economic due process doctrine with doctrine under contracts clause).

58. See R. HofstadTER, THE AMERICAN POLITICAL TRADITION 55 (1948). De Tocqueville was impressed by social equality in the United States during the 1830s. 1 A. DE TOCQUEVILLE, DEMOCRACY IN AMERICA 48-55 (P. Bradley trans. 1945). Despite the wide dispersion of productive property 
consisted exclusively of individuals or tiny firms whose activities, except when the state interceded to restrict competition, were coordinated through market relations. ${ }^{59}$ Companies were incorporated by special legislative charter. These charters often conferred privileges such as protection from competition in order to encourage investment in needed infrastructure. As capital became more plentiful, however, the procedure of incorporation by special charter came to be viewed as a source of corruption and as a means for conferring substantial economic benefits on the few. ${ }^{60}$ Jacksonians fought successfully to supplant legislative charters with general incorporation statutes that would confer the privileges of incorporation on anyone meeting certain formal requirements. ${ }^{61}$ Because their target was economic privilege, Jacksonians advocated greater commercial competition and a lesser government role on egalitarian grounds. ${ }^{62}$

Jacksonian democrats did not oppose private property but private power, the dangers of which they saw embodied in state-granted economic privilege. With the accession of Jackson appointees to the Supreme Court, led by Roger Taney, similar attitudes found expression in constitutional law. ${ }^{63}$ Although it employed the Constitution to protect individual property rights, ${ }^{64}$ the Taney Court showed less solicitude for property rights associated with monopoly privileges. ${ }^{65}$ With respect to corporations, the

in small units, however, two large classes, blacks and women, held little property. Moreover, a nascent urban factory system had already begun to develop. See A. SCHLESINGER, THE AGE OF JACKSON 32-33, 334-49 (1945).

59 . In the 1830 s, only a private entity with the extraordinary financial resources of the Second National Bank of the United States, the most powerful financial organization of its day, could afford to have a number of branch offices. Yet the Bank's central office was staffed by only three administrative employees. Other important economic enterprises of the time had equally rudimentary organizations. See A. Chandler, The Visible HaNd: The Managerial Revolution in AMerican BusiNESS $30,37,43,45-46$ (1977).

60. See B. HAMMOND, BANKS AND POLITICS IN AMERICA 326-68 (1957); R. HOFSTADTER, supra note 58, at 54-66; A. SCHLESINGER, supra note 58, at 334-49.

61. See A. SCHLESINGER, supra note 58, at 336-39;Louis K. Liggett Co. v. Lee, 288 U.S. 517, 548-64 (1933) (Brandeis, J., dissenting) (enumerating early general incorporation statutes and their progressive liberalization over course of nineteenth and early twentieth centuries).

62. Jacksonian egalitarianism emphasized equality of opportunity. Jacksonians believed, however, that truly equal opportunity would liberate the lower classes-the farmers, craftsmen, and laborers-and deprive only those few who were indolent. See R. HOFSTADTER, supra note 58, at 60-61. The competitive approach to commerce not only served political ends but corresponded with a new stage in American economic development in which the need for innovation was perceived as assuming greater importance than the need to attract scarce capital-the principal rationale for limiting competition. See S. BRUCHEY, THE ROOTS OF AMERICAN ECONOMIC GROWTH, 1607-1861, at 128-33 (1965); M. HORWITZ, THE TRANSFORMATION OF AMERICAN LAW, 1780-1860, at 110-11 (1977). The growth of the railroads, for example, would have been severely hampered had the old turnpike and canal monopolies retained legal force. See id. at 137-39.

63. See S. BRUCHEY, supra note 62, at 136-40 (Taney court prepared to aid commerce but suspicious of corporate power); C. SWISHER, ROGER B. TANEY 380-92 (1935) (same).

64. See, e.g., Bronson v. Kinzie, 42 U.S. (1 How.) 311 (1843) (statute impairing foreclosure rights violates contracts clause as applied to mortgages predating statute).

65. See, e.g., Charles River Bridge v. Warren Bridge, 36 U.S. (11 Pet.) 420 (1837) (interpreting corporate charter of bridge company to contain no implicit guarantee that state would not charter 
Court pursued a pragmatic course, extending corporate legal capacity in the federal courts for procedural purposes ${ }^{66}$ but refusing to equate corporations with natural persons for more substantive constitutional purposes. $^{67}$

Large-scale non-market forms of economic organization did not exist in the Jacksonian era because they were not economically necessary. ${ }^{68}$ Following the Civil War, however, new production and marketing techniques were developed. Freed from extensive government supervision by the passage of general incorporation statutes, ${ }^{69}$ large private organizations evolved in sectors of the national economy in which greater efficiency or earnings could be achieved by the replacement of market with managerial forms of economic coordination. ${ }^{70}$ Although intervention by the state once had generally been necessary to sustain monopoly conditions, it now became increasingly evident that intervention was necessary if such conditions were to be suppressed..$^{71}$ Typically, in those areas of the economy in which mass production techniques were most successful, a few large firms came quickly to dominate. ${ }^{72}$ By the 1920 s the transformation of many sectors of the economy was virtually complete. ${ }^{73}$

\section{B. Economic Due Process}

The rise of industrial organization transformed the economic face of American society. In particular, inequalities in private economic power grew sharper as ownership of productive property became increasingly concentrated, ${ }^{74}$ while the number of persons without significant productive

competing company); cf. M. HORWITZ, supra note 62, at 134 ("The Charles River Bridge case represented the last great contest in America between two different models of economic development [statechartered monopoly and laissez faire competition]."); S. KUTLER, PRIVILEGE AND CREATIVE DESTRUCTION: THE CHARLES RIVER BRIDGE CASE 155-71 (1971) (Charles River Bridge case symbolized contest between two views of how private property could best be made to serve public interest).

66. See Louisville, C. \& C. R.R. v. Letson, 43 U.S. (2 How.) 497 (1844) (shareholders may appear in federal court under corporate name in diversity action even though not all are citizens of state in which corporation chartered).

67. Bank of Augusta v. Earle, 38 U.S. (13 Pet.) 519, 586-87 (1839) (corporations are not "citizens" within meaning of privileges and immunities clause). Justice Taney, the author of Earle, "rejected the applicability of [the privileges and immunities] clause to the corporation, not because textual analysis or controlling precedents forbade, ... . [but] because . . . he chose to deny, by reason of his economic and poltical outlook, the enhancement of strength that such constitutional protection would give." F. FRANKFURTER, THE COMMERCE Clause 65 (1937).

68. See A. ChaNdLER, supra note 59 , at 50 .

69. Cf. Frug, supra note 48, at 1099-1120 (contrasting emancipation of private corporations with subordination of municipal corporations to state supervision).

70. See A. CHANDLER, supra note 59 , at 372-75.

71. See H. THORELLI, THE FEDERAL ANTITRUST POLICY 160-63 (1954) (summarizing economic and political factors leading to passage of Sherman Act in 1890).

72. See A. CHANDLER, supra note 59, at 365-68.

73. See id. at $455-56$.

74. The period from 1880 to 1920 was one of rapid consolidation of control over productive property through such devices as vertical and horizontal corporate expansion, merger, and the use of trusts 
property and dependent on industrial employment expanded. ${ }^{75}$

The inadequacy of classical liberal democratic theory had been its failure to confront the problem of private economic power. ${ }^{76}$ As the twentieth century approached, state legislatures began addressing working and social conditions accompanying the concentration of private power in business. ${ }^{77}$ At the same time, the Supreme Court assumed the burden of interpreting the limits imposed on democratic authority by property rights in the new era of large-scale private organization. Justice Stephen Field, perhaps the Justice most influential in developing the basic concepts underlying economic due process, commented upon the new economic world that had emerged since the close of the Jacksonian era:

As population and wealth increase-as the inequalities in the conditions of men become more and more marked and disturbing-as the enormous aggregation of wealth possessed by some corporations excites uneasiness lest their power should become dominating in the legislation of the country, and thus encroach upon the rights or crush out the business of individuals of small means-as population in some quarters presses upon the means of subsistence, and angry menaces against order find vent in loud denunciations - it becomes more and more the imperative duty of the Court to enforce with a firm hand every guarantee of the Constitution . . . . It should never be forgotten that protection to property and to persons cannot be separated .... [T]here can be neither prosperity nor progress where either is uncertain. ${ }^{78}$

In the 1870 s, the Court had seemed ready to acknowledge the growing importance of private power even in the absence of state-granted privilege.

and holding companies. See A. CHANDLER, supra note 59, at 285-376. By 1937, 394 corporations, or less than one-tenth of one percent of all corporations reporting for federal tax purposes, owned about forty-five percent of total corporate assets. See TEMPORARY NATIONAL ECONOMIC COMM. ON THE CONCENTRATION OF ECONOMIC POWER IN THE UNITEd STATES, 77TH CONG., 1ST SESS., FINAL REPORT OF THE EXECUTIVE SECRETARY 169 (Comm. Print 1941). Similarly, in 1937, five percent of estates reporting for federal estate tax purposes possessed over fifty percent of corporate stock reported. See id. at 168.

75. Non-agricultural employment rose in absolute terms by a factor of seven between 1860 and 1920 and from $41 \%$ to $73 \%$ of all gainful employment. E. KIRKLAND, A HistorY OF AMERICAN ECONOMIC LIFE 484 (3rd ed. 1951). At the same time, profound qualitative changes in non-agricultural employment were occuring, as a largely craft-oriented system was transformed into mass industry. See R. WIEBE, THE SEARCH FOR ORDER, 1877-1920, at 22-27, 37-43 (1967) (describing changes in American life as result of concentration and impersonalization of economic power).

77. See generally Brandeis, Labor Legislation, in 3 HISTORY OF LABOR IN THE UNITED STATES, 1896-1932, at 397 (1935); S. FINE, LAISSEZ FAIRE AND THE GENERAL-WELFARE STATE 357-62, 364 (1956).

78. Address by Justice Stephen Field, Supreme Court Centennial Celebration (Feb. 4, 1890), quoted in H. CARSON, THE SUPREME COURT OF THE UNITED STATES: ITS HISTORY AND ITS CENTENNIAL Gelebration 723 (1891). 
In Munn v. Illinois, ${ }^{79}$ the Court introduced the innovative concept of "business affected with a public interest" in upholding rate regulation of privately owned grain elevators. ${ }^{80}$ The Munn principle plausibly could have evolved to differentiate between private property having merely personal significance and private property affecting the public, thus acknowledging the dual nature of property in constitutional law. ${ }^{81}$

In perhaps the earliest case identified with the economic due process tradition, however, the Court took a decisively different course. In Santa Clara County v. Southern Pacific Railroad, ${ }^{82}$ the Court announced its unanimous position that corporations were "persons" for the purposes of the equal protection clause of the Fourteenth Amendment. ${ }^{83}$ Subsequent cases extended due process and other Bill of Rights protections to corporations. ${ }^{84}$ By refusing to distinguish between corporate and individual ownership of property, the Court did not overrule Munn, but did lay the basis for treating all property ownership, whether that of a craftsman or of a manufacturing corporation, as though equally nonthreatening to personal autonomy and equally crucial to preserving it. $^{85}$

\section{94 U.S. 113 (1877).}

80.

Property does become clothed with a public interest when used in a manner to make it of public consequence, and affect the community at large. When, therefore, one devotes his property to a use in which the public has an interest, he, in effect, grants to the public an interest in that use, and must submit to be controlled by the public for the common good, to the extent of the interest he has thus created.

Id. at 126. See generally Scheiber, The Road to Munn: Eminent Domain and the Concept of Public Purpose in the State Courts, in 5 PERSPECTIVES IN AMERICAN HISTORY 329 (D. Fleming \& B. Bailyn eds. 1971) (discussing historical background to concept of "public purpose").

81. Munn was handed down at a time when businessmen were expanding and consolidating their operations into integrated organizations of national significance. See note 74 supra. It would have been difficult to find a major corporation that did not use its property "in a manner to make it of public consequence, and affect the community at large." The expansive potential of Munn was not lost on business; the case became the "bete-noir of laissez-faire conservativism." A. PAUL, CONSERVATIVE CRISIS AND THE RULE OF LAW 8 (1960). In fact, however, the Munn principle was progressively narrowed until its scope was limited virtually to public utilities. See Ribnik v. McBride, 277 U.S. 350, 357 (1928) (invalidating New York rate regulation for employment agencies because not "business affected with a public interest"). With the collapse of economic due process, the Munn principle came under attack on the opposite flank as too restrictive of legislative authority over economic activity, and was abandoned. See Olsen v. Nebraska ex rel. Western Reference \& Bond Ass'n, 313 U.S. 236, 245-46 (1941) (overruling Ribnik and sustaining Nebraska price-fixing statute against due process challenge).

82. 118 U.S. 394 (1886).

83. Id. at 396. Santa Clara thus marked a reversal, within the space of thirteen years, of the restrictive view taken by the Court in the Slaughter-House Cases, 83 U.S. (16 Wall.) 35, 81 (1873). Whether the framers of the Fourteenth Amendment surreptitiously intended it to encompass corporations has been the subject of a much-debated "conspiracy theory." For a history of that debate, see Graham, "Builded Better than they Knew,": The Framers, the Railroads, and the Fourteenth Amendment (pt. 1), 17 U. PITT. L. REV. 537, 581 (1956) (concluding that, at time amendment was drafted, no one was sufficiently aware of possible future development of due process and equal protection clauses to have intended that they benefit business).

84. See note 13 supra.

85. For the Constitution to be useful to corporations, it was necessary not only that corporate 
The substance of the Court's economic due process jurisprudence, invalidating some though by no means all economic legislation brought before it, has been well documented. ${ }^{86}$ Of particular interest here, however, are cases concerning employment contracts, typically between an organized business and an individual employee. In these cases, the Court's stress on three rhetorical themes-individualism, formal equality, and government paternalism-obscured the issue of relative economic power. ${ }^{87}$

First, the Court employed the rhetoric of individualism, despite the fact that, by virtue of Santa Clara and subsequent cases, the constitutional protection afforded property was available to organizations possessing a fictitious personality as well as to individuals. ${ }^{88}$ Characteristically, the Court purported to focus its concern on the individual employee. ${ }^{89}$ When a business was discussed, its organized status was typically not considered, and no attempt was made to get beyond the fiction of its legal parity with natural persons. ${ }^{90}$

entitlement to constitutional rights be recognized, but also that, substantively, these rights protect interests of importance to corporations. See Miller, The Forest of Due Process Law: The American Constitutional Tradition, in DUE PROcess: Nomos XVIII, at 322-23 (J. Pennock \& J. Chapman eds. 1977). Santa Clara simply indicated that the Court was taking a position more protective of corporate property. If the Munn principle had been extended rather than narrowed, the significance of Santa Clara would have to be reduced. Indeed, following the 1930 s, with the virtually total retreat of the Court from constitutional adjudication in the economic realm, the debate over Santa Clara and the constitutional corporate person lost its urgency. But see p. 1860 infra (doctrine of constitutional corporate person assumed renewed importance in 1970s).

86. See, e.g., P. BREST, supra note 56, at 705-53; A. KELly \& W. HARBISON, THE AMERICAN CONSTITUTION 525-46, 689-725 (4th ed. 1970); W. SwINDLER, supra note 55; B. WRIGHT, THE GROWTH OF AMERICAN CONSTITUTIONAL LAW 148-99 (1942). Two studies have traced the development in the late nineteenth century of concepts and attitudes underlying economic due process. See A. PAUL, supra note 81; B. TWISs, LAWYERS AND THE CONSTITUTION (1942).

87. These themes suggest nostalgia for Jacksonian liberal capitalism, which was characterized by individual rather than corporate enterprise, by a diffusion of economic power, and by a state identified with the creation of monopoly rather than with its suppression. The jurisprudence of Justice Stephen Field, an important foundation for economic due process, has been analyzed in these terms. See McCurdy, Justice Field and the Jurisprudence of Government-Business Relations, in AMERICAN LAW AND THE CONSTITUTIONAL ORDER 246 (L. Friedman and H. Scheiber eds. 1978).

88. The Court made frequent appeal to the self-reliance of workers and their ability to fend for their own interests in the marketplace. See, e.g., Adkins v. Children's Hosp., 261 U.S. 525, 553 (1923) (emancipation of women counters any contention that minimum wage law for women is justified on grounds that women "must be given special protection or be subjected to special restraint in [their] contractual or civil relationships"); Coppage v. Kansas, 236 U.S. 1 (1915) (employee who entered into "yellow dog" employment contract was "a free agent, in all respects competent, and at liberty to choose what was best from the standpoint of his own interests"); Lochner v. New York, 198 U.S. 45, 57 (1905) (implying that maximum-hour statute for bakers would be justified if "bakers as a class ... [were] not able to assert their rights and care for themselves without the protecting arm of the State, interfering with their independence of judgment and action").

89. See, e.g., Coppage v. Kansas, 236 U.S. 1, 14 (1915) (freedom of contract is "as essential to the laborer as to the capitalist, to the poor as to the rich; for the vast majority of persons have no other honest way to begin to acquire property, save by working for money"); Lochner v. New York, 198 U.S. 45, 57 (1905) (case involves "question of which of two powers or rights shall prevail-the power of the State to legislate or the right of the individual to liberty of person and freedom of contract").

90. In cases involving disputes between unions and employers, for example, the Court emphasized the collective power of workers while simultaneously considering corporations as individual persons. 
Second, the rhetoric of individualism lent plausibility to the Court's stress on the voluntary nature of an employment contract and on the formal equality of parties to it. ${ }^{91}$ The Court countered arguments that no parity existed between employer and employee in bargaining by emphasizing the formal agreement of both parties to a contract. It refused to look behind that agreement to the bargaining that determined the substance of the contract terms. ${ }^{92}$ The Court was apparently willing to acknowledge the role of power only in relationships characterized by loss of free will on the part of the employee. ${ }^{93}$

Third, while ignoring the significance of aggregated private power, the Court by contrast came to regard the power of the state as having undesirable consequences. In this view, government intervention in the employeremployee relationship paternalistically impugned the dignity of the individual worker and restricted his freedom to decide what was best for himself. ${ }^{94}$ It followed that the rights of the employee must be preserved from derogation even by legislation intended to protect the employee.

In Coppage v. Kansas, the Court stated as a rhetorical question what in fact was the fundamental doctrinal difficulty posed by the denial of the constitutional significance of private economic power:

\section{Can the right of making contracts be enjoyed at all, except by parties}

In Gompers v. Bucks Stove \& Range Co., 221 U.S. 418 (1911), Justice Lamar wrote:

But the very fact that it is lawful to form [unions], with multitudes of members, means that they have thereby acquired a vast power, in the presence of which the individual may be helpless. This power, when unlawfully used against one, cannot be met, except by his purchasing peace at the cost of submitting to terms which involve the sacrifice of rights guaranteed by the Constitution; or by standing on such rights and appealing to the preventive powers of a court of equity. When such an appeal is made it is the duty of government to protect the one against the many as well as the many against the one.

Id. at 439.

91. Sec, e.g., Adair v. United States, 208 U.S. 161, 175 (1908) ("In all such particulars the employer and the employe have equality of right, and any legislation that disturbs that equality is an arbitrary interference with the liberty of contract which no government can legally justify in a free land."); Lochner v. New York, 198 U.S. 45, 56 (1905) ("Of course, the liberty of contract relating to labor includes both parties to it. The one has as much right to purchase as the other to sell labor.")

92. See, e.g., Adkins v. Children's Hosp., 261 U.S. 525, 558 (1923) ("Certainly the employer by paying a fair equivalent for the service rendered, though not sufficient to support the employee, has neither caused nor contributed to her proverty. On the contrary, to the extent of what he pays he has relieved it.")

93. See, e.g., Coppage v. Kansas, 236 U.S. 1, 8, 17 (1915) (conceding that "each party when contracting is inevitably more or less influenced by the question whether he has much property, or little, or none," but asserting that "on this record, we have nothing to do with any question of actual or implied coercion or duress, such as might overcome the will of the employe by means unlawful"); Lochner v. New York, 198 U.S. 45, 52 (1905) (noting that employer was charged with having "required" employee to work more than sixty hours per week, but that no opinion below construed this "as referring to any physical force being used to obtain the labor of the employee. It is assumed that the word means nothing more than the requirement arising from voluntary contract . . . .")

94. See Lochner v. New York, 198 U.S. 45, 62 (1905) (to allow state to regulate hours of work would allow it to "assume the position of a supervisor, or pater familias, over every act of the individual"); note 88 supra (citing other examples). 
coming together in an agreement that requires each party to forego, during the time and for the purposes of the agreement, any inconsistent exercise of his constitutional rights? ${ }^{95}$

To maintain basic economic sufficiency and comfort, people entered into relationships with business institutions that the Court, even contemporaneously, would have condemned as in violation of constitutional rights had the relationship been with the state. ${ }^{96}$ Economic inequality undermined liberalism by denying many of the benefits of living in a liberal society to those without significant property. ${ }^{97}$

\section{The Legacy of 1937 and Free Expression}

From 1937 to 1941, central economic due process holdings of the previous fifty years were abandoned, ${ }^{98}$ and in a more general sense the spirit of economic due process was repudiated.99 Bellotti, however, has once again posed the question of the constitutional protection due corporate prerogatives in the use of private property. To confront that question, it is necessary to consider the ambivalent transformation of constitutional law that occurred in the late 1930s.

\section{A. The Ambivalence of 1937}

Commentators have accurately labeled the adoption of a "rational relation" approach to economic legislation a judicial "abdication" 100 of powers

95. Coppage v. Kansas, 236 U.S. 1, 13 (1915). But cf. Gompers v. Bucks Stove \& Range Co., 221 U.S. 418, 439 (1911) (private economic power of unions dangerous because businessman might be forced to bargain away constitutional rights).

96. See Hale, Force and the State: $A$ Comparision of "Political" and "Economic" Compulsion, 35 COLUM. L.REV. 149 (1935) (comparing instances of economic compulsion applied by government and condemned by Court as violative of rights with similar instances of compulsion applied privately and held protected by Constitution).

97. Cr. J. WEINSTEIN, THE CORPORATE IDEAl in THE LIBERAL STATE xiii-xv (1968) (early progressive legislation promoted by certain business leaders who saw that corporate responsibility and regulatory state offered only long-term political alternative to growing socialist sentiment).

98. See West Coast Hotel v. Parrish, 300 U.S. 379, 400 (1937) (overruling Adkins v. Children's Hosp. and, by implication, Lochner v. New York); Phelps Dodge Corp. v. NLRB, 313 U.S. 177, 187 (1941) (overruling Coppage v. Kansas and Adair v. United States); Olsen v. Nebraska, 313 U.S. 236, 244 (1941) (overruling Ribnik v. McBride).

99. See Lincoln Fed. Labor Union v. Northwestern Iron \& Metal Co., 335 U.S. 525, 536 (1949) (noting that Court "has steadily rejected the due process philosophy enunciated in the Adair-Coppage line of cases"); United States v. Carolene Products Co., 304 U.S. 144, 152 (1938) ("[Regulatory] legislation affecting ordinary commercial transactions is not to be pronounced unconstitutional unless in the light of the facts made known or generally assumed it is of such a character as to preclude the assumption that it rests upon some rational basis within the knowledge and experience of the legislators."); S. FINE, supra note 105, at 164 (during economic due process era "the judiciary placed itself between the public and what the public needed and helped to protect individuals who did not need protection against society, which did need it").

100. See L. TRIBE, supra note 42, at 450; McCloskey, Economic Due Process and the Supreme Court: An Exhumation and Reburial, 1962 SUP. CT. REV. 34, 38. 
of review. Minimum scrutiny made it possible for the government to address pressing economic issues of the Great Depression and Second World War and to reformulate the relationship between government and business. ${ }^{101}$ Yet change entailed the substantial destruction of a system of individual rights: most of the larger body of property rights cases dating to the origins of constitutional adjudication was abandoned along with economic due process. ${ }^{102}$ It is far from clear, however, that the economic or property interests of individuals are any less important to the preservation of personal autonomy now than before. ${ }^{103}$

101. The immediate effect was to remove the judiciary as a substantial obstacle to New Deal economic legislation. In a broader sense, the events of 1937 to 1941 completed a gradually developing shift in the perception of government. Legislative power was no longer inherently limited, but rather was subject to restriction going beyond minimum judicial scrutiny only in certain "privileged" areas. See L. TRIBE, supra note 42 , at 565 . This new attitude is exemplified by Griswold v. Connecticut, 381 U.S. 479 (1965), which relied not merely on the Ninth Amendment, but also on the First, Third, Fifth, and Fourteenth in finding a constitutional right of privacy encompassing the use of contraceptives.

102. Pre-1937 cases defending property rights had invoked the "inherent limits" on government as well as the contracts, takings, due process, and equal protection clauses. See notes 52-55 supra. After 1937, the Court continued from time to time to invoke arguments suggesting natural or inherent limits on government, but not in defense of property rights. See, e.g., Moore v. City of E. Cleveland, 431 U.S. 494, 503 (1977) (city ordinance limiting relatives who could live together as "family" held violative of due process "precisely because the institution of the family is decply rooted in this Nation's history and tradition"); Rochin v. California, 342 U.S. 165, 172 (1952) (pumping of defendant's stomach to recover narcotics evidence violative of due process as "conduct that shocks the conscience"). The due process clause was reduced to a virtual nullity in the economic realm. See G. GUNTHER, CASES AND MATERIALS ON CONSITUTIONAL LAW 540 (10th ed. 1980) (No economic regulation invalidated on substantive due process grounds since 1937). The same holds true for the equal protection clause, though with some suggestion of rebirth in the 1970s. See jd. at 540 n.1, 693-96 (citing Burger Court cases invalidating economic and social legislation on equal protection grounds without explicitly invoking heightened scrutiny). The contracts clause fell into disuse within a few years after the Court's decision in Home Building \& Loan Ass'n v. Blaisdell, 290 U.S. 398 (1934) (upholding Minnesota law imposing moratorium on mortgage foreclosures because of depression emergency). But $c f$. Allied Structural Stecl Co. v. Spannaus, 438 U.S. 234 (1978) (holding that Minnesota law imposing certain requirements on company pension plans violated contracts clause as applied to pension agreements predating statute); United States Trust Co. v. New Jersey, 431 U.S. 1 (1977) (holding that legislative repeal of covenant governing transportation bonds impaired obligation of states' contracts with bondholders). The takings clause of the Fifth Amendment, as applied to the states through the Fourteenth, has seldom come before the Supreme Court since 1937, and when it has the Court has shown a strong tendency to sustain state legislative power. See, e.g., Agins v. City of Tiburon, 447 U.S. 255 (1980) (sustaining California zoning ordinace); Penn Central Transp. Co. v. New York City, 438 U.S. 104 (1978) (sustaining New York City's Landmarks Preservation Law). But see Kaiser Actna v. United States, 444 U.S. 164 (1979) (invalidating imposition of public servitude on commerical property without compensation).

103.

[T] ] dichotomy between personal liberties and property rights is a false one. Property does not have rights. People have rights. The right to enjoy property without unlawful deprivation, no less than the right to speak or the right to travel, is in truth, a "personal" right, whether the "property" in question be a welfare check, a home, or a savings account.

Lynch v. Household Finance Corp., 405 U.S. 538, 552 (1972) (interpreting civil rights jurisdictional statute, 28 U.S.C. $\S 1343(3)$, to apply to "property" as well as "personal" rights). See L. TRIBE, supra note 42, at 572-75 (arguing that minimum economic well-being is prerequisite to vindication of political rights); Michelman, The Supreme Court, 1968 Term-Foreword: On Protecting the Poor Through the Fourteenth Amendment, 83 HARV. L. REV. 7, 10 (1969) (arguing for imposition of duty on state to protect actively against "risks . . associated with paucity of income or wealth"). For a 
This Note has argued that a central difficulty for liberal democratic theory arises from the dual nature of property and from the problem of determining to what extent private rights should prevent society from legislating whatever degree of equality is necessary to make private rights meaningful. ${ }^{104}$ From a theoretical perspective, the Court's answer after 1937 was hardly more satisfactory than its answer before. The pre-1937 Court failed to recognize property as a basis for power; the post-1937 Court failed to recognize it as a basis for personal autonomy. In each case, the Court neglected to seek an accommodation between the possibility of democratic social change and the maintenance of a stable system of individual rights-first, by impeding efforts at democratic reform of the economic system, and subsequently, by substantially abandoning a system of substantive individual rights in order to make way for social change. ${ }^{105}$

In the place of property as the guardian of individual autonomy, modern constitutional jurisprudence has evolved a number of more specific "personal" rights. ${ }^{106}$ In the years since 1937, corporate lawyers have sought protection for their clients within the new fabric of rights just as they sought protection within the old. The personal nature of rights given emphasis after the 1930s and the judicial strategy of differentiating "degrees of scrutiny" have ensured, however, that corporations since 1937 by and large have not been the principal beneficiaries of constitutional rights adjudication. ${ }^{107}$ Yet First National Bank of Boston v. Bellotti gave a par-

persuasive statement of the interdependency of economic interests not now subject to constitutional protection and political rights that are, see San Antonio Independent School Dist. v. Rodriguez, 411 U.S. 1, 112 (1973) (Marshall, J., dissenting) (right to adequately funded education is basis for effective exercise of political rights). In the late 1960 s and early 1970 s the Court decided a number of cases extending procedural due process protection to the property of wage-earners and the poor. See, e.g., Fuentes v. Shevin, 407 U.S. 67 (1972); Goldberg v. Kelly, 397 U.S. 254 (1970); Sniadach v. Family Finance Corp., 395 U.S. 337 (1969).

104. See pp. 1842,1850 supra.

105. The career of Munn v. Illinois, see p. 1847 supra, illustrates this failure. The concept of "business affected with a public interest," while defining no convenient bright line, recognized implicitly the dual nature of property by asserting that the public had an interest in uses of private property that significantly affected the community at large. Yet the post-1937 Court discarded Munn for a weak rational relation standard, see note 81 supra, instead of aggressively developing a principle that would have allowed it to recognize that property ownership is a basis both for personal autonomy and for private power.

106. See L. TRIBE, supra note 42, at 564-67 (post-1937 constitutional jurisprudence has centered on doctrines involving freedom of expression and association, rights of political participation, rights of religious autonomy, rights of privacy and personhood, and equal protection).

107. Business corporations could not qualify for any of the "suspect classifications," such as race and alienage, triggering heightened equal protection scrutiny. The Court has also seemed unwilling to extend to corporate property the heightened procedural due process scrutiny protections of cases like Sniadach v. Family Finance, 395 U.S. 337 (1969), Goldberg v. Kelly, 397 U.S. 254 (1970), or Fuentes v. Shevin, 407 U.S. 67 (1972). The new substantive due process has been applied to protect only personal privacy interests. Cf. California Bankers Ass'n v. Schultz, 416 U.S. 21, 65 (1974) " 'Corporations can claim no equality with individuals in the enjoyment of a right to privacy." ") (quoting United States v. Morton Salt Co., 338 U.S. 632, 652 (1950)). Before 1975, much the same could have been said of free expression jurisprudence. Regulation of commercial speech was accorded only mini- 
ticular use of corporate property the degree of constitutional protection associated in modern law with "strict scrutiny." 108 Although the Bellotti decision does not confront the dual nature of property any more than predecessor decisions, the terms of its avoidance are more closely analogous to pre-1937 jurisprudence than to what followed. Like the economic due process cases, the decision sought to minimize the relevance of private power to constitutional analysis.

\section{B. Bellotti and the Spirit of Economic Due Process}

The Bellotti Court did not deny, as a factual matter, that the use of corporate property could influence the political process, ${ }^{109}$ just as the economic due process courts had not denied the advantages of wealth in the bargaining process. ${ }^{110}$ Like the economic due process courts, however, the Bellotti Court sought to minimize rhetorically the extent to which its holding could be viewed as a defense of private power. As in economic due process, the Court pressed the three themes of individualism, formal equality, and the danger of government paternalism.

First, just as the economic due process courts ostensibly focused their concern on the rights of individual workers, the Bellotti Court focused its concern on the rights of individual listeners. ${ }^{111}$ The Court did not address the corporate character of the "speaker" except to dismiss the relevance of the issue. ${ }^{112}$

Second, by identifying politics with voting, the Court was able to focus on the formal equality of citizens in the voting booth and ignore the impact of material inequality on the processes determining the substance of political choice. ${ }^{113}$ Just as the economic due process courts emphasized the

mal or rational relation scrutiny, and the standing of corporations, other than the press, to assert First Amendment speech rights had not been established. But see note 16 supra (citing pre-1975 cases in which First amendment claims brought by corporate litigants upheld without reference to corporate status). Business corporations were also successful in asserting Fourth Amendment rights. See, e.g., Marshall v. Barlow's, Inc., 436 U.S. 307 (1978) (requiring search warrant for OSHA inspection of business premises).

108. 435 U.S. 765 (1978).

109. See First Nat'l Bank of Boston v. Bellotti, 435 U.S. 765, 790 (1978) ("To be sure, corporate advertising may influence the outcome of the vote; this would be its purpose.")

110. See note 93 supra.

111. See First Nat'l Bank of Boston v. Bellotti, 435 U.S. 765, 777-83 (1978).

112. Sce id. at $\mathbf{7 7 6 .}$

113. The egalitarianism characteristic of earlier voting rights cases did not find expression in Bellotti or in Buckley v. Valeo, 42 U.S. 1 (1976). Compare Reynolds v. Sims, 377 U.S. 533, 567-68 (1964) (holding that importance of equality in voting justifies judicially directed reapportionment) and Harper v. Virginia Bd. of Elections, 383 U.S. 663, 668 (1966) (invalidating poll tax on grounds that wealth not germane to ability to participate intelligently in electoral process) with Buckley v. Valco, 424 U.S. 1, 49 n.55 (1976) (refusing to extend principles developed in earlier voting rights and fairness doctrine cases to allow legislature to address effects of material inequality on political speech and participation apart from voting and broadcast media) and First Nat'l Bank of Boston v. Bellotti, 435 U.S. 765, 790-91 (1978) (citing Buckley to deny that "government may restrict the speech of some 
worker's voluntary agreement, the Court emphasized the citizen's voluntary vote. In each case, the Court refused to consider as constitutionally significant any influence or power that did not overwhelm the individual will. ${ }^{114}$

Third, while ignoring the significance of private power, the Court did attach importance to state power. Legislation seeking to minimize the impact of material inequality on politics, like labor legislation in the view of the economic due process courts, was "paternalistic" and impugned the capacity of autonomous individuals to fend for themselves in the marketplace, whether of ideas or of labor. ${ }^{115}$

The marketplace model underlies the analytic link between Bellotti and economic due process. Central to the marketplace model is the concept of "voluntariness," which in practice can obscure all power relationships short of an outright overcoming of individual will. ${ }^{116}$ Political speech involves not just the spread of information, but also the power that comes of persuading political audiences. Today, access to political audiences can be purchased, ${ }^{117}$ as can, to some extent, the tools of persuasion. ${ }^{118}$ One need not belittle the importance of voting to political outcomes in the United States to recognize that next to the political power of the corporate speaker who can afford media advertising, the power of an individual voter to influence the political process is virtually symbolic. ${ }^{119}$

elements of our society in order to enhance the relative voice of others" "). But see id. at 809 (White, J. dissenting) (economic power of corporations "may, if not regulated, dominate not only the economy but also the very heart of our democracy, the electoral process"); cf. L. TRIBE, supra note 42, at 112935 (analyzing Burger Court decisions such as Buckley as shielding privileges and power of wealth from attempts at legislative redistribution).

114. See First Nat'l Bank of Boston v. Bellotti, 435 U.S. 765, 789 (1978) (challenged restriction could be justified only by showing that "corporate advocacy threatened imminently to undermine democratic processes"). Refusing to consider relative access to speech opportunities may be consistent with a self-expression theory of the First Amendment, but it does not comport with an approach, such as the Bellotti Court purported to take, emphasizing social interests in discussion and dialogue. See Chevigny, supra note 6 , at $189-90$ (Bellotti's refusal to consider relative voice in political context is inconsistent with First Amendment theory emphasizing open dialogue).

115. See First Nat'l Bank of Boston v. Bellotti, 435 U.S. 765, 791 n.31 (1978) ("The First Amendment rejects the 'highly paternalistic' approach of statutes like [the Massachusetts statute at issue] which restrict what the people may hear.")

116. See notes 46 \& 93 supra.

117. See S. DUNN \& A. BARBAN, ADVERTISING: ITS ROLE IN MODERN MARKETING 163-71, $457-$ 75 (3d ed. 1974) (discussing advertising departments as primarily sales departments selling access, and discussing media strategies for cost-effective access to appropriate audiences).

118. See id. at 305-08 (psychological objectives of typical modern advertising); Reed \& Coalson, Eighteenth Century Legal Doctrine Meets Twentieth Century Marketing Techniques, 11 GA. L. REV. 733, 735-53 (1977) (techniques of emotional conditioning in advertising); $c f$. W. COMANOR \& T. WILSON, ADVERTISING AND MARKET POWER 239 (1974) ("[R]elative advertising expenditures appear to be more important than relative prices in allocating sales among industries.")

119. Cf. S. Lydenberg, Bankrolling Ballots: The Role of Business in Financing State Ballot Question Campaigns (Council on Economic Priorities, 1979) (reporting 16 case studies of corporate campaigns in connection with state referenda; of cases studied, corporate-backed side won two-thirds of campaigns in which it outspent opponents, none in which it did not) (on file with Yale Law Journal). The Bellotti Court conceded that corporate wealth may influence politics. See note 109 supra. 


\section{Corporate Speech}

Buckley v. Valeo ${ }^{120}$ introduced a subtle but important doctrinal shift by equating money to support speech activities with pure speech. ${ }^{121}$ Like the introduction of "liberty of contract," this doctrinal shift checked the legislature in attempting to limit the extent to which wealth differentials could be translated into power differentials. Bellotti, like the Santa Clara case it reaffirmed and extended, ensured that corporations would benefit from this expansion of the constitutional prerogatives of property. Together, Buckley and Bellotti provide the basic precedents for a judicial defense of the exercise of corporate power in the realm of politics.

Since 1937 it has been clear that the state may constitutionally promote material equality. ${ }^{122}$ Yet the state's interest in promoting equality in democratic politics should be even less contestable. ${ }^{123}$ Democracy becomes oligarchy when political power and opportunities for political participation are permitted to concentrate in the hands of a few. The issue that is contestable is the extent to which this commitment to equality extends beyond formal equality in the polling booth.

Here, the analogy to economic due process is most instructive. In 1937, the Court confronted the fact that the defense of formal equality, of "voluntariness" in the broad sense, was destroying for many precisely the individual autonomy and spontaneity that economic rights were supposed to protect. ${ }^{124}$ After Bellotti and Buckley, the Gourt must confront the similar fact that those decisions, by blocking legislative attempts to limit the extent to which concentrated economic power can be translated from the private into the public sphere, have impaired the very rights that the decisions purportedly sought to protect. Political speech requires an audience, and the efficacy of political speech diminishes or increases with access to appropriate audiences. The Bellotti decision allows access to political audiences to be allocated in ways that more closely reflect the dominance of corporate wealth in the economy. The result of the decision is a sacrifice on both sides of the liberal balance. The power of the legislature to promote political equality has been diminished; at the same time, the value of the right to speak has been undermined for those without control over

120. 424 U.S. 1 (1976).

121. See note 18 supra.

122. The basic federal constitutional limits on democratic choice in this regard remain at present the takings clause, the contracts clause, and minimum scrutiny under the due process and equal protection clauses.

123. See Reynolds v. Sims, 377 U.S. 533, 560-61, 565 (1964) (upholding judicially directed reapportionment on grounds that "the fundamental principle of representative government in this country is one of equal representation for equal numbers of people, without regard to race, sex, economic status, or place of residence" and that "every citizen has an inalienable right to full and effective participation in the political processes of his State's legislative bodies").

124. See West Coast Hotel v. Parrish, 300 U.S. 379, 399 (1937) (conceding "exploitation of a class of workers who are in an unequal position with regard to bargaining power and are thus relatively defenceless against the denial of a living wage"). 
corporate wealth. ${ }^{125}$

\section{Free Expression without Corporate Rights}

Despite the Court's manipulation of the "marketplace of ideas" metaphor, corporate speech does little, if anything, to serve speech interests. ${ }^{126}$ The court implicitly conceded that corporate speech involves no self-expression or self-fulfillment interests, there being no corporate "self."127 The issue in Bellotti was the right of managers to spend general corporate funds, not the right of any individual to speak or make use of personal resources. The Court argued that the interests at stake were not "speaker" but "listener" interests, and that corporate speech helped ensure the diversity of ideas available to the individual citizen. ${ }^{128}$ But allowing legislatures to restrict the use of corporate property would intrude upon the speech rights of no individuals. Corporate owners and managers would be as free as before to advocate their political views. The unavailability of corporate funds for this purpose would simply place those individuals on a more even footing with fellow citizens; it would decrease the number or diversity of views available to individual voters. ${ }^{129}$

125. The potential impact is increased by a number of decisions of the 1970 s narrowing public access to relatively inexpensive fora. See Greer v. Spock, 424 U.S. 828 (1976) (handbilling may be prohibited on military base); Hudgens v. NLRB, 424 U.S. 507 (1976) (labor picketers may be excluded from privately owned shopping center); Lehman v. City of Shaker Heights, 418 U.S. 298 (1974) (placard space may be denied to political advertisements on public buses); Lloyd Corp. v. Tanner, 407 U.S. 551 (1972) (handbilling may be prohibited in privately owned shopping center). It is also significant that basic land use patterns are changing with the displacement of many public downtown commercial areas by suburban shopping malls and by the growth of privately held residential communities. See Note, Private Abridgment of Speech and State Constitutions, 90 YALE L.J. 165, 168-72 (1980); cf. Miami Herald Publishing Co. v. Tornillo, 418 U.S. 241 (1974) (invalidating Florida statute requiring newspapers to provide cost-free reply space).

126. See T. EMERSON, THE SYSTEM OF FREEDOM OF EXPRESSION 6-7 (1970) (identifying basic speech interests served by First Amendment as self-fulfillment, discovery of truth, popular participation in government, and substitution of reason for force in politics).

127. See First National Bank of Boston v. Bellotti, 435 U.S. 765, 775-76 (1978) (denying that inquiry should be into what rights corporations "have").

128. Id. at 781-83.

129. Cf. Cammarano v. United States, 358 U.S. 498, 513 (1959) (holding that denial of tax deduction for political advocacy related to petitioner's business does not violate of First Amendment, but reflects "a determination by Congress that since purchased publicity can influence the fate of legislation . . ., everyone in the community should stand on the same footing as regards its purchase so far as the Treasury of the United States is concerned").

Allowing legislatures to restrict flows of corporate wealth into politics would hardly eliminate all political inequality. Democratic theorists regard the inequitable distribution of personal, no less than corporate, wealth as undermining the potential for a functioning democracy. See, e.g., Dahl, supra note 31, at 16 (" $[\mathrm{A}]$ country committed to procedural democracy must either place effective limits on the extent to which economic resources can be converted into political resources, or else ensure that economic resources are much more equally distributed than they are in the United States at present.") The provisions of the Federal Election Campaign Act that were applied in Buckley v. Valeo, 424 U.S. 1 (1976), in fact, place ceilings on political contributions by individuals. See note 18 supra. Permitting legislative restrictions on corporate political spending is therefore only a partial response to political inequality; however, that provides no argument against allowing such restrictions. First, restricting 
A more apt metaphor for democratic politics is a democratic town meeting. ${ }^{130}$ In this context, parliamentary rules placing reasonable limits on speaking time serve to broaden, not narrow, access to the floor. Moreover, selling speaking time to the highest bidder would hardly be likely to promote a diversity of expression, particularly when the political agenda included items in which the wealthy had a stake.

One rationale for corporate free speech rights is that they are necessary to ensure protection of forms of organized or institutional expression-by political organizations and the press-that are incontestably vital to the system of freedom of expression. Such institutional expression, however, can be protected without granting corporate speech rights.

\section{Political Associations}

Association is often required for effective individual expression, particularly of unpopular viewpoints. ${ }^{131}$ Political associations typically lack independent means of financial support and hence are particularly vulnerable to discriminatory regulation. ${ }^{132}$ The Court has recognized the right of freedom of association protecting the expression of a political group without considering whether the group has adopted a corporate or other form of business organization. ${ }^{133} \mathrm{~A}$ problem of definition would arise if a forprofit business corporation claimed entitlement to constitutional protection as a political association. The Court has never extended the status to groups whose primary purpose is not political advocacy in some form. ${ }^{134}$

corporate speech reduces political inequality and enriches political discussion with no real sacrifice of individual speech rights or interests. Second, it must be emphasized that the liberal balance between legislative power to effectuate social change and individual rights is a balance. Complete political, or for that matter material, equality could not be achieved without an overwhelming exercise of power and sacrifice of rights. See Kennedy, supra note 40 , at 212 . The tension inherent in liberal democracy-between rights and powers, individual and society-can be eased but not eliminated.

130. Cf. A. MEIKLEJOHN, POLITICAL FREEDOM 24-28 (1960) (using town meeting metaphor for poltical speech).

131. See NAACP v. Alabama ex rel. Patterson, 357 U.S. 449, 460 (1958).

132. The development of the freedom of association principle, in fact, received impetus from efforts by certain states to expel the NAACP through the use of "business regulations." See NAACP v. Alabama ex rel. Flowers, 377 U.S. 288 (1964) (voiding injunction issued by Alabama courts against NAACP prohibiting it from doing business in Alabama); Louisiana ex rel. Gremillion v. NAACP, 366 U.S. 293 (1961) (affirming federal injunction against Louisiana courts to prevent enforcement of business regulations requiring NAACP to produce membership lists); NAACP v. Alabama ex rel. Patterson, 357 U.S. 449 (1958) (voiding state court order in suit by state to enforce business regulations requiring NAACP to produce membership lists).

133. See, e.g., NAACP v. Alabama ex rel. Flowers, 377 U.S. 288, 309 (1964) ("This case, in truth, involves not the privilege of a corporation to do business in a State, but rather the freedom of individuals to associate for the collective advocacy of ideas.")

134. Compare NAACP v. Button, 371 U.S. 415 (1963) (prohibiting application of Virginia antisolicitation statute to association's use of litigation as form of political advocacy) with Garcia v. Texas State Bd. of Medical Examiners, 384 F. Supp. 434 (W.D. Tex. 1974), affd mem., 421 U.S. 995 (1975) (refusing to invalidate on freedom of association grounds Texas statutes restricting establishment of health maintenance organizations). 
The exclusion of for-profit ${ }^{135}$ business corporations from the category of incorporated political associations would not discriminate against those espousing a "business" point of view or decrease the overall diversity of views expressed. On the contrary, those individuals espousing a "business" point of view could establish political associations with personal funds. In the absence of corporate speech rights, legislatures could restrict flows of corporate cash to political associations. The effect would be to place political associations on a more fair and even financial footing. Differences in funding would more nearly reflect differences in the personal commitment of supporters to particular points of view rather than differences in access to corporate funds.

\section{Freedom of the Press}

In a concurring opinion to Bellotti, Chief Justice Burger argued that a failure to protect corporate speech would implicate First Amendment rights of the corporate press and media conglomerates. ${ }^{136}$ The press plays a crucial role in national political discourse, and the Chief Justice may correctly have assumed that the profit-making corporate form is essential to large sectors of the press. Nevertheless, the argument that protection of corporate speech is essential to preserve the press implies the untenable corollary that before corporate constitutional rights were recognized-at the earliest with Santa Clara, let alone Bellotti-the press clause was an empty letter for the institutional press.

History and policy support recognition that the press clause has an institutional significance separate from the speech clause. This suggestion is not new. ${ }^{137}$ Most discussion to date has focused on whether members of the press should be granted rights different from those protecting other speakers under the speech clause. ${ }^{138}$ In the context of a denial of corporate rights under the speech clause, however, recognition of a distinct institutional press clause would serve more narrowly to guarantee the First Amendment rights of the corporate press, as distinguished from other cor-

135. The common feature of all definitions of not-for-profit status is that net earnings are not distributed to those who own or control the organization. See Hansmann, The Role of Nonprofit Enterprise, 89 YALE L.J. 835, 838 (1980). Not all not-for-profit organizations would qualify as political associations. See Garcia v. Texas State Bd. of Medical Examiners, 384 F. Supp. 434 (W.D. Tex. 1974), aff'd mem., 421 U.S. 995 (1975) (health maintenance organization not treated as political association).

136. First Nat'l Bank of Boston v. Bellotti, 435 U.S. 765, 796 (1978) (Burger, C.J., concurring).

137. See Stewart, "Or of the Press", 26 HASTINGS L.J. 631, 633 (1975) (press clause "extends protection to an institution. The publishing business is, in short, the only organized private business that is given explicit constitutional protection.")

138. Special press rights proposed have included press access and a reporter's privilege. See Abrams, The Press Is Different: Reflections on Justice Stewart and the Autonomous Press, 7 HoF. STRA L. REV. 563, 587-91 (1979). 
porations, without necessarily granting the institutional press rights different from those enjoyed by other speakers.

Recognition of an institutional press clause would require the development of a constitutional definition of the press. The courts have assumed similar burdens in other contexts. ${ }^{139}$ The most difficult distinction involved in defining the press in order to distinguish the corporate press from other corporations is the distinction between corporate editors and corporate advertisers. But such a distinction is already embedded in the speech doctrines of the present Court. On the basis of content, the Court presently distinguishes commercial speech-that is, "expression related solely to the economic interests of the speaker and its audience"-from political speech..$^{140} \mathrm{~A}$ newspaper, however, might advocate editorially an economic transaction in which it had an interest. Unless the Court wished to invade the editorial function, it would have to find the speech political on institutional rather than content-based grounds. ${ }^{141}$ The Court's present First Amendment jurisprudence thus does not allow it to avoid the definitional line-drawing suggested here.

\section{Conclusion}

Jackson's America has passed, and legislation must compensate for the loss of a social order uniquely conducive to liberal democratic politics. Given the reality of a corporate industrial economy, one approach might simply be the abandonment of liberal democratic ideology in favor of one stressing corporate and organizational values. ${ }^{142}$ If liberal democratic principles are retained, however, the recognition of corporate rights makes the coexistence of vigorous democracy and vigorous individual rights of all

139. For example, the establishment and free exercise clauses can only be applied on the basis of a definition of religion. See id. at 580-82 (comparing tasks of defining "press" and defining "religion"). A definition of the press should not be technologically restrictive, but should include those institutional media whose business is the dissemination of expression, whether informational or artistic. Cases prior to 1978 protecting instances of institutional expression without reference to corporate rights might provide a basic body of precedent. See note 16 supra.

140. Central Hudson Gas \& Elec. Corp. v. Public Serv. Comm'n, 100 S.Ct. 2343, 2349 (1980); cf. note 19 supra (commercial speech entitled to lesser constitutional protection than political speech).

141. Courts have consistently held that discussions of products or services in news accounts or consumer guides are not commercial but political speech. See, e.g., United Medical Laboratories, Inc. v. CBS, 404 F.2d 706 (9th Cir. 1968), cert. denied, 394 U.S. 921 (1969) (extending First Amendment protection to television reports concerning services performed by certain medical testing laboratories); Bon Air Hotel, Inc. v. Time, Inc., 295 F. Supp. 704 (S.D. Ga. 1969) (extending First Amendment protection to magazine comments on hotel accomodations and services). Stripping editorial speech af full First Amendment protection whenever the publisher could be shown to have an economic interest in content would open newspapers to searching inquiries into motives and editorial policy. A safer approach than content review, even within the context of the Court's present First Amendment jurisprudence, would be reliance on the sort of institutional definition of the press suggested here.

142. See, e.g., G. LODGE, THE. NEW AMERICAN IDEOLOGY (1978) (characterizing "Lockean individualism" as outmoded and instead proposing society based on more "holistic" values, led by managerial elite). 
sorts unnecessarily problematic. A strong system of individual rights places constraints on the power of a democratic majority, yet in another sense remains essential to peaceful democratic social change. If nothing else, the security of individual rights is part of the social confidence necessary to contemplate and undertake change. Nevertheless, if individual rights protect not just individuals and relationships of personal scope, but also features of the broader structure of the national economy, then political proposals for economic and social change will almost necessarily derogate from individual rights. Much as in the 1930s, the extent to which corporations can invoke individual rights to challenge legislation aimed at promoting structural change unnecessarily aggravates the dilemma of effectuating social change and preserving individual rights.

The argument has been made that with the collapse of economic due process, corporate constitutional personality became an innocuous doctrine because of the lack of substantive constitutional law of interest to corporations. ${ }^{143}$ This view should be updated. The renewed vitality of the Santa Clara doctrine threatens to resuscitate the spirit of economic due process in new substantive areas. Moreover, it creates a disincentive to extend increased constitutional protection to individual economic rights when doing so would redound primarily to the benefit of corporate business and revive economic due process in a more literal sense. A searching reconsideration of Santa Clara itself would probably lead to the conclusion that the decision is an unfortunate vestige of the economic due process era, that by granting civil rights to powerful institutions, hinders efforts to achieve liberal democracy characterized both by vigorous democracy and by vigorous individual rights.

143. See Graham, supra note 9, at 210 ("[S]elf-knowledge and self-limitation have drawn the teeth of federal substantive due process. In consequence, corporate personality by itself is scarcely a formidable doctrine.") But cf. Van Alstyne, The Recrudescence of Property Rights as the Foremost Principle of Givil Liberties, The First Decade of the Burger Court, LAW \& CONTEMP. PROB., Summer 1980, at 66 (1980) (Burger Court's adjudication of constitutional rights in areas such as free expression and search and seizure has tended to advance interests of property owners at expense of non-property owners). 